\title{
Indication of the Financial Indicators of the Activity of Football Sports Clubs as an Indicator of a Pilot for the Establishment of Joint-Stock Companies (Case Study)
}

\author{
Abdallah Mohamed Mohy Eldien ${ }^{1}$ \\ ${ }^{1}$ Lecturer at the Faculty of Physical Education for Men, Alexandria University, Egypt
}

\begin{abstract}
The main purpose of this study is the financial performance of the activity of football Egypt analysis through income and expense analysis and net profit for the activity of football in order to provide investors and members and the public of financial information for making investment decisions in the activity of football and researcher used the analytical manner case study consisted the sample in the Egyptian Al-Ahly during the period 2007 to 2013 were the most important results and a positive financial indicators of revenue over expenditure during that period The present study is believed to contribute in evaluating the football clubs from an economical perspective.
\end{abstract}

Key words: Financial indicators, establish joint-stock companies

\section{Introduction}

$\mathrm{F}$ ootball is widely considered to be an established and distinct business, Jones, K. (2003) Sport organizations and football clubs in particular have experienced several faces in their organizational form. During the 1970s and early 1980 s clubs adapted their organizational design to a more professional and bureaucratic form moving away from the simply-structured and amateur-governed style of management. The transformation of football clubs from non-profit into profit-oriented organizations had radical consequences for the club's position in the national, European and international sport market and in the manner which those companies were managed. Football today has evolved into a market, the main characteristic of which is the investment of uncounted billions. Extravagant expenditure for transfers, astronomical sums for signing of contracts with footballers, disputes and battles among sponsors to get 'star' footballers to promote and advertise their products, endless negotiations to obtain a share of the TV rights, professional managers trying to find the model team for potential investors, piece together the current soccer environment the football industry remains a business activity that promotes the financial growth of individuals that are closely involved with this sport (Dimitropoulos, P. 2010) ( Boscá , J. E., Liern, V., Martínez, A., \& Sala, R. (2009)

soccer clubs have started to turn into a structure that is similar to the global companies with their enormous transfer and investment expenses. Since the beginning of 1980 s, soccer has started to settle as a brand-new industry by way of the European soccer clubs. European soccer clubs have built new stadiums that have helped the European soccer clubs to increase their revenues especially in England (Szymanski, S., \& Smith, R,1997) The fact that football clubs, like any other companies, have a product to sell and consumers to satisfy is another important reason for considering football as a business. it might be fair to conclude that football has always been a business to some extent, but reached unimagined dimensions in the last decade of the twentieth and the first decade of the twenty-first century ( Andreff , W., \& Staudohar, P. D. 2000) The budgets of Soccer clubs' budgets grow with the growth in soccer industry. Therefore, the growing expenses increase the financing needs of the clubs. In general, corporations which have financing needs, meet these needs with debt and equity financing. At the same time, the improvements in financial markets and the increase in the diversity of financial instruments increase the financing opportunities. This situation canalizes the soccer clubs to the capital markets. Though quite a few soccer clubs meet their financing needs from capital markets by issuing stocks and these stocks are to be traded in exchanges ( Buraimo , B., Simmons, R., \&Szymanski, S. 2006) In the last two decades, a series of events hav e occurred that turned professional football in Europe into an industry with unprecedented economic dynamism. The transformation of football clubs into commercial companies encouraged some investors to take prominent positions in the capital of such companies; investing very large amounts of money ( Kesenne, S. 2007).

number of studies in literature, intended to determine the performance of football clubs. More generally, liquidity 
and profitability indicators to be high and liability indicators to be low is a situation that businesses and investors desire. Hence, two of the liquidity indicators, six of the liability indicators, and three profitability indicators were used for financial evaluations

Benchmarking is a process by which to compare one's property against itself, the competition, or even the industry as a whole. In comparing with oneself, either to a historical perspective or to budget, trends, weaknesses, and opportunities for improvement can be identified. In the financial areas, such benchmarks and comparisons are normally quantitative in nature and are in the forms of financial ratios (Raymond, S., Schmidgall, Agnes L., \& DeFranco, 2004)

Profitability indicators are used in interpreting the profitability level, which is the final purpose of the business. The Earnings per Share ratio, as can be understood from its name, is the profit ratio that shareholders have at the end of a period. As expected, this ratio is wanted to be high. Net Capital/Equity ratio is the ratio that shows equity capital profitability of the business ( Ecer, F., \& Boyukaslan, A. ,2014)

Financial statements are the most reliable sources that give current and periodical information about the financial situation of businesses. These statements help business partners and stakeholders do financial analyses of the related period or current period. Financial analysis is fulfilled with basic purposes, such as making business decisions in a healthy way, defining financial policies, obtaining required sources, and measuring financial adequacy. Thanks to this, business owners ensure their capitals, business managers can realize decision making, planning and auditing activities, stakeholders have the opportunity to evaluate activity results and results like profitability ( Akdogan, N., Tenker, N., 1998)

Whereas these analyses can be used in financial planning, they can also be used in the measurement of realizing activities. Additionally, the most commonly used method to make financial analysis is the ratio analysis. Ratio analysis is the expression and mathematical interpretation of the relationship between two items aimed to be examined in the financial statements (Buker, S., Asikoglu, R. Guven, S., 2010)

although clubs are still non-profit organizations by law but the FIFA correspondences Egyptian Football Association that each participating clubs in the Egyptian league to turn to professional clubs in football before the beginning of the 2012-2013 season. It also paragraph 38 of the draft statute of the clubs and to suggest that sports clubs in order to develop their resources and increase their revenues establishment of the contribution of the club contributes companies and its members shall marketing slogan, clothes and soccer team, buying and selling of players and clubs that specialized departments established sub-accounts under the general budget whereas Study and analysis of financial indicators of the activity of football sports clubs, for long periods helps the decision makers of the board members of sports clubs departments in deciding to transfer Activity football into joint stock companies, as well as help investors, customers and members and has the desire to invest in football to take the decision to buy or not shares by identifying the level of income and expenses and profit margin for a long time and this is evident in the statistics used by the researcher processors financial statements obtained by the researcher were finding statistical relationships for a time period is 7 years

\section{Material and Methods}

\section{Aim Study}

The study aims to analyze the financial performance of the activity of football the club Al-Ahly for the period 1- 72007 to $31-12-2013$

\section{The study questions}

What signify financial indicators of the activity of Al Ahli club football Egyptian in the period 1- 7- 2007 to 31- 122013 ?

\section{Study procedures}

\section{Study method}

Research methodology is descriptive method using case study method.

\section{Study community: Egyptian sports clubs .}

\section{Study Sample: al- ahly club}

\section{Data collection tools}

The researcher used accredited documents adopted by Alahly club consisted of the budget and the final account for the years 2007 to 2013 A period in which the researcher was able to obtain official documents in which and the researcher depends on the financial reports approved Activity soccer and football academy and income and expenses of foreign leagues

\section{Statistical analysis:}

Statistical analysis was done with SPSS software package by using Mean, Median, Skewness and Standard deviation 


\section{Results}

Table 1

Statistical semantics for study sample in variables $\mathrm{N}=7$

\begin{tabular}{|c|c|c|c|c|c|c|}
\hline $\begin{array}{r}\text { Statistical } \\
\text { semantics }\end{array}$ & Min value & Max value & Mean & Median & $\begin{array}{c}\text { Standard } \\
\text { deviation }\end{array}$ & Skewness \\
\hline variables & & & & & & \\
\hline Incomes & 29068961 & 158304662 & 70768456.29 & 64417011 & 41621630.94 & 1.862 \\
\hline Outcomes & 27742355 & 154721752 & 63502296.43 & 45498558 & 46136742.27 & 1.659 \\
\hline Net profit & -21327434 & 27240287 & 7266159.86 & 8421976 & 15482166.03 & -0.866 \\
\hline
\end{tabular}

Table (1) shows that the overall study sample data is These values indicate to recognize equinoctial normal moderate and shows normal distribution for the sample, distribution.

the coefficient values ranging between (-0.866 to 1.862$)$.

Table 2

Net profit of incomes in relation to outcomes for the same year

\begin{tabular}{|c|c|c|c|}
\hline Fiscal year & $\begin{array}{c}\text { Incomes (Egyptian } \\
\text { pound) }\end{array}$ & $\begin{array}{c}\text { Outcomes (Egyptian } \\
\text { pound) }\end{array}$ & $\begin{array}{c}\text { Net profit (Egyptian } \\
\text { pound) }\end{array}$ \\
\hline $\begin{array}{c}1 / 7 / 2006 \text { to } \\
30 / 6 / 2007\end{array}$ & 57739232 & 45498558 & 8421976 \\
\hline $\begin{array}{c}1 / 7 / 2007 \text { to } \\
30 / 6 / 2008\end{array}$ & 43386713 & 34964737 & 19378100 \\
\hline $\begin{array}{c}1 / 7 / 2008 \text { to } \\
30 / 6 / 2009\end{array}$ & 67204157 & 47826057 & 1326606 \\
\hline $\begin{array}{c}1 / 7 / 2009 \text { to } \\
30 / 6 / 2010\end{array}$ & 29068961 & 27742355 & 27240287 \\
\hline $\begin{array}{c}1 / 7 / 2010 \text { to } \\
30 / 6 / 2011\end{array}$ & 64417011 & 37176724 & -21327434 \\
\hline $\begin{array}{c}1 / 7 / 2011 \text { to } \\
30 / 6 / 2012\end{array}$ & 75258458 & 96585892 & 3582910 \\
\hline $\begin{array}{c}1 / 7 / 2012 \text { to } \\
31 / 12 / 2013\end{array}$ & 158304662 & 154721752 & 7266159.857 \\
\hline Average & 70768456.29 & 63502296.43 & \\
\hline
\end{tabular}

Shape 1

Incomes \& outcomes in the same year

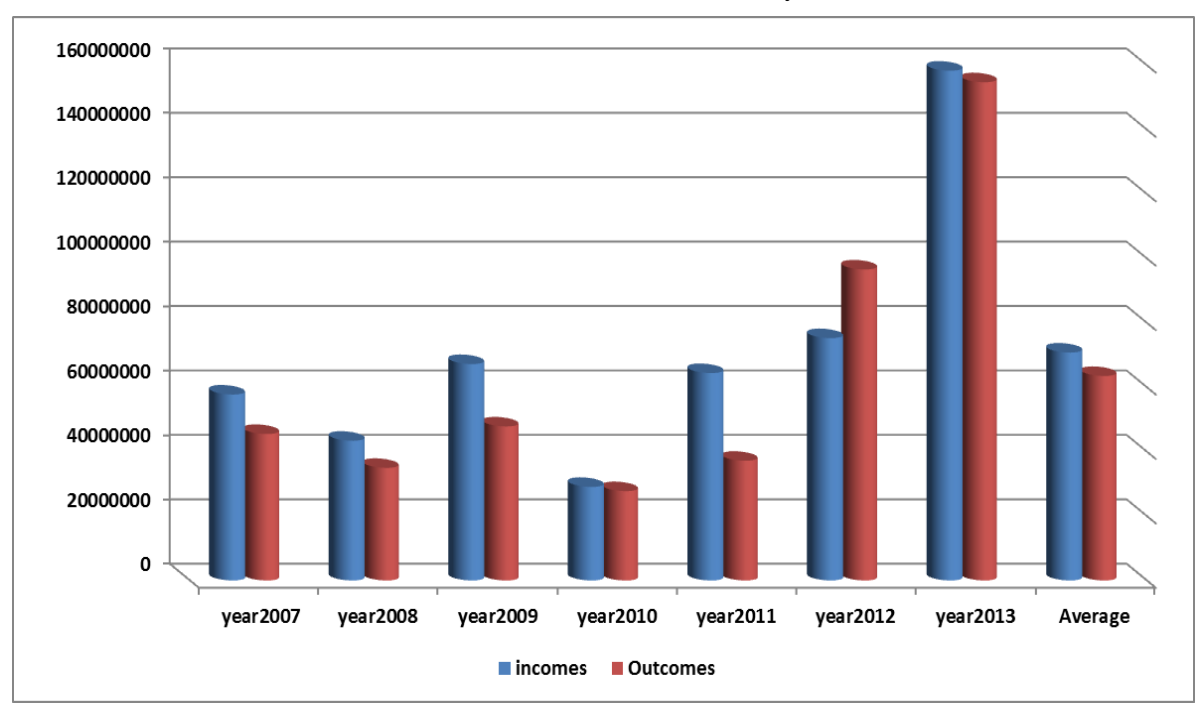


Shape 2

Net profit in the same year

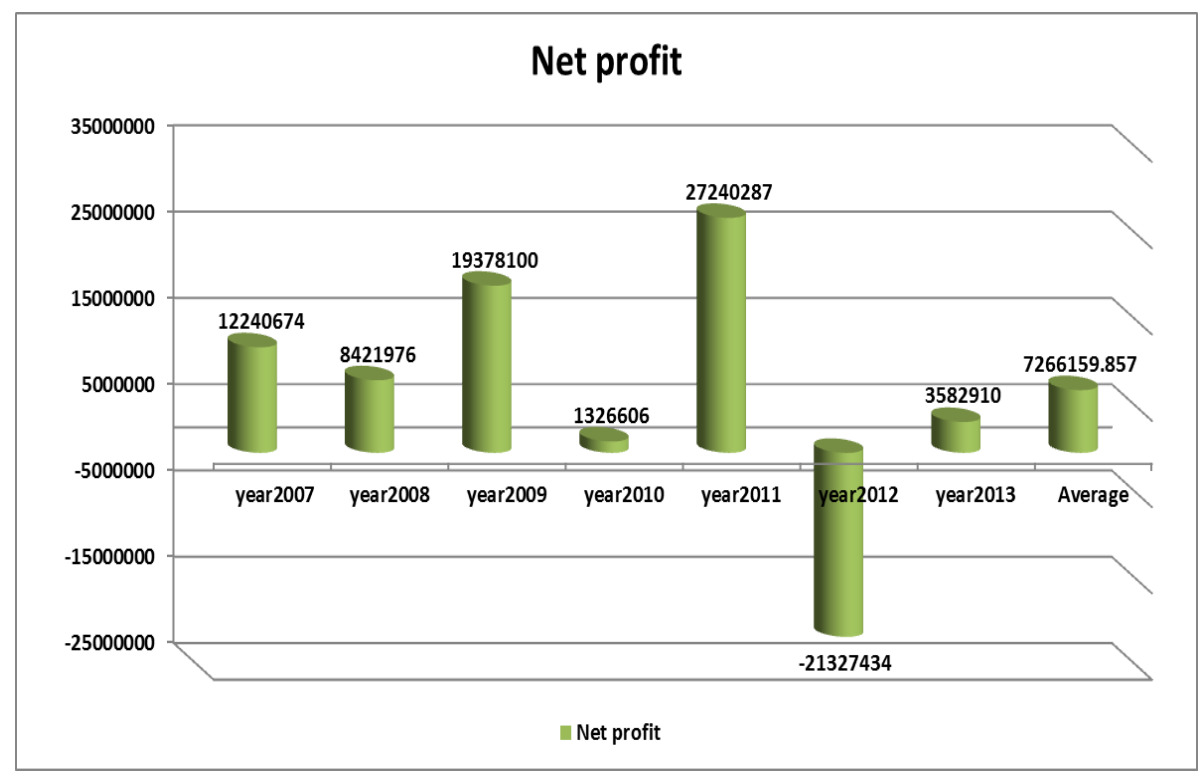

\section{Discussion}

It is seen from the table (1.2) of the statistical characterization of the study data and Diagram that the total revenues Activity football club Al-Ahli of Egypt during the period 2007 to 2013 amounted to 495379193 pounds with an average annual income 70,768,456.29 pounds .

While total expenses for the same period amounted to 444516075 pounds at an average annual expenses $63,502,296.46$ pounds.

While the net profit of the activity of football during the period 2007 to the period 2014 the amount of $50,863,118$ with an average annual net profit of 7,266,159.857 pounds.

Table also indicates (2) The year 2012 saw a deficit of revenue football totaled $21,327,434$ pounds due researcher this deficit to political and sporting events experienced by Egypt and influenced the public and the activity of football especially those stop the league as a sport income, which led to the broadcast revenues affected and nonattendance masses of matches which affected returns on match day as well as the reduction of sports sponsorship revenue .

It is clear from the previous view that the financial indicators of the activity of football is an element important to clarify the financial role of the activity of football for investors, the public and members and to assist in making investment decisions in football, as well as members of boards of sports clubs manage to make conversion Activity football into joint stock companies and determine the value of the stock based decisions Financial Indicators.

To measure the financial success of a football club, the most relevant indicator is the current revenue of the sports society, Current revenues are considered the benchmark of financial success of the club, based on available, easy to compare information( Deloitte ,2015)

performance evaluation of the firms is generally done within the context of financial analyses. Furthermore, the use of financial ratios in the process of financial performance evaluation is very common. More clearly, financial ratios produced from the data in firms' income statements and balance sheets are being used in studies for financial performance evaluation for many years. This is because, financial ratios present the information that is necessary for decision making (Singh, A. J., \& Schmidgall, R. S ,2002) ( Yalcin, N., Bayrakdaroglu A., Kahraman C., 2012

one of the things that must be done in such a situation is to evaluate the performances of football clubs, which are unbreakable parts of this economy, by examining their financial structures ( Ecer, F., \& Boyukaslan, A, 2014) Therefore, analyzing thefinancial statements of football clubs it is possible to understand which stage of the life cycle the football company is in and to predict a firm's failure (Carmine Zoccali ,2011)

Ratio analysis is one of the core topics in any accounting curriculum. Ratio analysis expresses a relationship between two shapes by dividing one number by another it presents financial data in another light and gives 
controllers and managers another (Weygandt, J. J., Kieso, D. E., Kimmel, P. D., \& DeFranco, A. L. , 2005)

The main purpose of these financial reports is to give customers and investors respectively an overview of the work of European football by comparing the various football markets and notes that, on average, $60 \%$ of the Football study is at the present time for business ( André, W. B. ,2006) afinancial analysis tools are ideal tools for evaluating institutions performance because of their ability on the profitability of the organization, and efficiency and balance financial and directions taken in the growth evaluation, as well as compared to the performance of other companies working in the same field, and this kind of analysis by most of the parties that have a relationship with the institution, such as management, investors and lenders to ensure the safety of their investment and the adequacy of revenues ( Zoghbi, H. M. (2000) so assessment of financial performances of clubs is quite important for managers, investors, credit lending institutions, competitors, and other stakeholders. This is because, financial performance success of the clubs become an important role on sporting success ordering However, even though one of the basic elements of the sporting success is financial structure, attention is attracted to the fact that financial performance assessments regarding the clubs by using financial ratios is not being done frequentlyFor this purpose (Kulikova, L. I., \& Goshunova, A. V., 2013)

assessment of financial performances of clubs is quite important for managers, investors, credit lending institutions, competitors, and other stakeholders. This is because, financial performance success of the clubs become an important role on sporting success ordering However, even though one of the basic elements of the sporting success is financial structure, attention is attracted to the fact that financial performance assessments regarding the clubs by using financial ratios is not being done frequentlyFor this purpose Soccer is an important sector for the economies with the growing revenues. On the other hand, financing needs also increase based on the growing industry. Therefore, many of soccer clubs have started to issue stocks to meet their financing needs (Sevil, T., Kamışlı, S., \& Kamışlı, M , 2014)

Must speed conversion of football clubs, sports activity offered to companies are created by the clubs themselves or in cooperation with legal persons and sell shares and securities and holds the buying and selling of players, care and sports marketing slogan Club (Salameh, M. A., \& Hassan, H,2008)

\section{Conclusion}

A decision to transfer Activity football club Al-Ahli of Egypt to joint-stock companies, as well as a decision contribute depends on the extent of knowledge of the financial indicators of the activity of football and it turned out through the financial statements of the activity of football analysis for the period 01.07.2007 to 12.31.2013 The results to the existence of a positive profit margin for the year as revenue results indicated that the average gross revenue higher than the average revenue during the seven years.

\section{References}

1. Akdogan, N., \& Tenker, N. (1998), Finansal Tablolar ve Mali Analiz Teknikleri, 6. Basım. Ankara: Gazi Büro Kitabevi, 12-13.

2. André, W. B. (2006), Football as an international business an Anglo-German comparison. European Journal for Sport and Society, No(8)pp 342 - 352

3. Andreff, W., \& Staudohar, P. D. (2000), The evolving European model of professional sports finance. Journal of Sports Economics, 1 (3), 257-276.

4. Boscá, J. E., Liern, V., Martínez, A., \& Sala, R. (2009), Increasing offensive or defensive efficiency? An analysis of Italian and Spanish football. Omega - The International Journal of Management Science, 37, 63-78.

5. Buker, S., Asikoglu, R., \& Guven, S. (2010), Finansal Yönetim”, 6.Bask1. Ankara: Sözkesen Matbaacılık

6. Buraimo, B., Simmons, R., \&Szymanski, S. (2006), English football. Journal of Sports Economics, 7(1), 2946.

7. Carmine Zoccali. (2011), The role of financial indicators in the life of Italian football clubs, Rivista Di Issn 1825-6678 Diritto Ed Economia Dello Sport. VII (3),

8. Deloitte. (2015), Football Money League - Commercial breaks, Sports Business Group, Manchester.

9. Dimitropoulos, P. (2010), The Financial performance of the Greek football clubs , Xophyia - Choregia Sport Management International Journal , 6(1).

10. Ecer, F., \& Boyukaslan, A. (2014), Measuring performances of football clubs using financial ratios: the gray relational analysis approach, American Journal of Economics, 4(1): 62-71.

11. Jones, K. (2003), Let's not forget: football is meant to be a game, not a business. The Independent, London.

12. Kesenne, S. (2007), The peculiar international economics of professional football in Europe. Scottish Journal of Political Economy, 54, 388-399. 
13. Kulikova, L. I., \& Goshunova, A. V.(2013), Measuring efficiency of professional football club in contemporary researches, World Applied Sciences Journal, 25 (2): 247-257.

14. Raymond, S., Schmidgall, Agnes L., \& DeFranco, (2004), Ratio analysis financial benchmarks for the club industry, The Journal of Hospitality Financial Management. 12(1).

15. Salameh, M. A., \& Hassan, H. (2008), Feasibility study to convert some sports clubs for the institutions work, Journal of the Faculty of Physical Education, University of Alexandria.

16. Sevil, T., Kamışlı, S., \& Kamışlı, M . (2014), Analyzing the interactions between European sport indexes, International Journal of Business and Social Science. 5, 10(1).

17. Singh, A. J., \& Schmidgall, R. S.(2002), Analysis of financial ratios commonly used by US lodging fnancial executives, Journal of Retail \& Leisure Property, 2. 201213.

18. Szymanski, S., \& Smith, R. (1997), The English football industry: Profit, performance and industrial structure. International Review of Applied Economics, 11 (1), 37-41.

19. Weygandt, J. J., Kieso, D. E., Kimmel, P. D., \& DeFranco, A. L. (2005). Hospitality financial accounting. Hoboken, NJ: Wiley.

20. Yalcin, N., Bayrakdaroglu, A., \& Kahraman, C. (2012), Application of fuzzy multicriteria decision making methods for financial performance evaluation of Turkish manufacturing industries, Expert Systems With Applications, 39. 350-364.

21. Zoghbi, H. M. (2000), Management and Financial Analysis, Dar Thought for printing, publishing and distribution: Jordan. 